\title{
Addressing the tax challenges of e-commerce transactions
}

\author{
Susanna Hartanto \\ Master of International Taxation at Texas A\&M University, USA \\ susannahartanto@tamu.edu
}

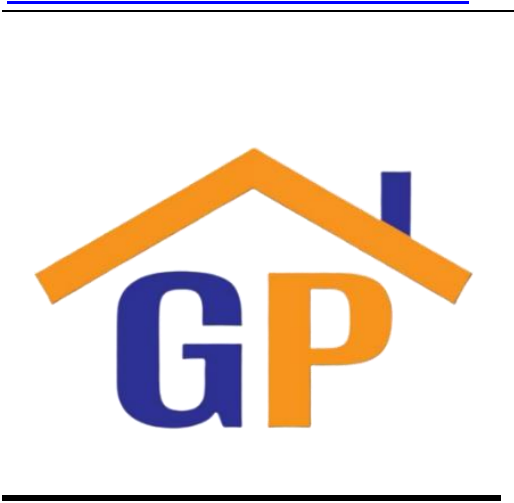

Article History

Received on 8 June 2020

$1^{\text {st }}$ Revision on 9 June 2020

$2^{\text {nd }}$ Revision on 23 June 2020

$3^{\text {rd }}$ Revision on 25 June 2020

Accepted on 2 July 2020

\begin{abstract}
Purpose: This study aimed to explore e-commerce taxation in Indonesia including some factors that were supporting and also challenging the implementation of e-commerce taxation.
\end{abstract}

Research Methodology: Interviews were conducted from the side of fiscus (Directorate General of Taxation) and taxpayers in ecommerce industry. Data collection used semi-structured interview, observation, and documentation. Data analysis of this research was using descriptive method.

Results: The result of this study proves that taxation in ecommerce industry has not been implemented in a good manner. Socialization to e-commerce taxpayers should be conducted in more structured and comprehensive ways.

Limitations: The limitation of this study was the amount of interviewees due to time limitation. In future research, the amount of interviewees can be added and split into four types of ecommerce transactions according to Directorate General of Taxation Circular No 62 Year 2013.

Contribution: A clear and fair e-commerce tax rules should be prepared in good manner to detect e-commerce transactions by government. Socialization to e-commerce taxpayers should be conducted in more structured and comprehensive ways to collect taxation from e-commerce transactions.

Keywords: E-Commerce, Digital taxation, Tax, Unified approach

How to cite: Hartanto, S. (2020). Addressing the tax challenges of e-commerce transactions. International Journal of Financial, Accounting, and Management, 2(1), 29-39.

\section{Introduction}

E-commerce transactions emerged as a consequences of the new virtual business model used by some multinational entities to expand their business operations abroad in the international landscape. According to Cambridge Business English Dictionary (Cambridge University Press, 2019), e-commerce can be defined as the business of buying and selling goods and services over the internet. Doing business using a virtual model is just a new method of exchanging goods or services through the internet that has the same effect of an exchange made by a traditional business model through a retail store. But digitalisation of the economy has enabled business enterprises to be heavily involved in the economic life of a jurisdiction without a significant physical presence.

Merchant Machine, a research institution in E-Commerce from United Kingdom released list of top 10 countries which have the biggest e-commerce growth in the world. According to Merchant Machine (Machine, 2019), Indonesia was number one with 78\% of e-commerce growth in 2018. Average money spent in e-commerce was $\$ 228$ or around Rp 3,19 million per person. $17,7 \%$ of respondents bought airline and hotel ticket through online, $11.9 \%$ respondents spent their money on clothing and footwear, while the third category is medical and beauty with $10 \%$ respondents. One of the most powerful strength that supports e-commerce growth in Indonesia is more than 100 million of internet users which make e-commerce industry is the new money maker industry. 
According to Indonesian Central Bureau of Statistics (Statistik E-Commerce, 2019), released on 18 December 2019, during 2018 from 13,485 e-commerce business, there were 24,821,916 transactions with amount almost IDR 17.21 trillion. Since 2014, Euromonitor has already stated that e-commerce transactions in Indonesia has already reached US\$ 1,1 Million. In the last decade, Indonesian Central Bureau of Statistics noted that e-commerce industry in Indonesia has been growth around $17 \%$ with total amount of 26.2 million unit of businesses .

According to Soemitro (Resmi, 2019: 1), tax is a compulsory contribution based on regulations to the government to defray the expenses incurred in the common interest of all, without reference to special benefit conferred. In General Tax Provisions \& Procedures Law No 28 of 2007, chapter 1 , article 1 point 1 , tax can be defined as a compulsory contribution to the state which is payable by any individual or entity that is enforced based on the law, without any direct benefit in return and is used for the maximum welfare of the people. Every business must be impacted by taxation either the business is conducted by personal taxpayers or corporate taxpayer, including ecommerce industry.

E-Commerce transactions growth will increase potential government income through taxation. Doing business through e-commerce will be much easier and needs lower costs in comparison with brick and mortar stores. Higher sales with lower operational cost will make higher profit and higher tax. But it is not easy as it seems for Directorate General of Taxation to implement tax rules to e-commerce tax payers. There are lots of challenges that have to be faced and overcomed in e-commerce taxation. Middle to low income of e-commerce business usually does not have any formal form of corporation, either in the form of Perseroan Terbatas (PT) or Commanditaire Vennootschap (CV), so they rejected to pay tax, while in middle up income of e-commerce business, the challenge is more complicated, even those tax payers has already got formal form of corporation, but they tried to avoid taxation by not having any office or representatives in Indonesia. This brings another challenges to have comprehensive regulations for e-commerce taxation. Government has already tried to but current regulations still do not have anti avoidance rule

Some researches have already done to show potential revenue of e-commerce transactions (Aprilia, Astuti, \& Nuzula, 2013) and (Makalalag, 2016). Both of them also agreed that there is a great potention for government to earn high amount of revenue through e-commerce taxation either from Income tax or Value Added Tax of e-commerce transactions, but there must be great efforts to implement e-commerce taxation rules through intensification. From above background this study made to explore e-commerce taxation in Indonesia, analyze implementation of taxation including some factors which are supporting the implementation of e-commerce taxation and some factors that will be constraints for the taxation implementation in e-commerce transactions and how further regulations will be needed as general anti avoidance rules especially economic substance from Unified Approach (Pillar One) of OECD.

\section{Literature review and hypothesis development}

\subsection{Tax}

According to Soemitro (Resmi, 2019: 1), tax is a compulsory contribution based on regulations to the government to defray the expenses incurred in the common interest of all, without reference to special benefit conferred. Meanwhile in General Tax Provisions \& Procedures Law No 28 of 2007, chapter 1, article 1 point 1 , tax can be defined as a compulsory contribution to the state which is payable by any individual or entity that is enforced based on the law, without any direct benefit in return and is used for the maximum welfare of the people. Every business must be impacted by taxation either the business is conducted by personal taxpayers or corporate taxpayer, including ecommerce industry. According to Adriani (Waluyo, 2017: 2), tax obligation depends on subject and object of taxation. One of income tax object is income from e-commerce.

\subsection{E-Commerce}

According to Cambridge Dictionary (Cambridge University Press, 2019), e-commerce can be defined as the business of buying and selling goods and services over the internet. Nowadays, e-commerce is part of e-lifestyle that can make life easier by doing sell and buy 
activities from anywhere through online. In e-commerce business, according to Irmawati (Irmawati, 2011), there are some components that make it difference from offline business:

a. Product: various products can be sold through online

b. Place to sell: social media or need domain and hosting

c. Order: email or direct order through website or mobile application

d. Payment: cash, credit card, internet banking, transfer, internet payment (paypal, etc)

e. Delivery method: package delivery, salesmen or direct download (for software, song, movie,etc)

f. Customer service: through email, online form, chatting, etc

\subsubsection{Type of E-Commerce Transactions}

According to Rivera (Rivera, 2018), Four principal categories of e-commerce are:

1. Business to Business (B2B): this type of e-commerce involves companies doing business with each other. One example is manufacturers selling to distributors and wholesalers selling to retailers. Dropshipping is an example of this type of e-commerce

2. Business to Consumer (B2C): B2C consists of businesses selling to the public through shopping cart software, without needing any human interaction. This is what most people think of when they hear "e-commerce." An example of this is Amazon.

3. Consumer to Business ( $\mathrm{C} 2 \mathrm{~B})$ : In $\mathrm{C} 2 \mathrm{~B}$ e-commerce, consumers post a project with a set budget online, and companies bid on the project. The consumer reviews the bids and selects the company. Elance is an example of this.

4. Consumer to Consumer $(\mathrm{C} 2 \mathrm{C})$ : This takes place within online classified ads, forums or marketplaces where individuals can buy and sell their goods. Examples of this are Craigslist, eBay and Etsy.

According to Directorate General of Taxation Circular No 62 Year 2013 about taxation for ecommerce transactions, there are 4 types of e-commerce transactions:

a. Online Marketplaces

Online marketplaces are activities to give place of business as internet store for merchant to sell goods or services. In this type of e-commerce, there is registration fee or rent fee for displaying goods or services through internet mall. Sellers usually are lots of permanent sales. Offer, order and payment will be done through online system, but delivery method is both through offline and online system. Sellers will be charged by online marketplace as commission fee of goods or service sales. Example of online marketplaces are Bukalapak, Tokopedia, Shopee

1. Classified Ads

Classified ads are activities to give place ad or time to display advertisement of goods and or services by the advertiser through website. This website is prepared by classified ads management. Number of sellers are lots. Type of sellers in classified ads are incidental sellers who advertised not in frequent basis. Offers are done through online, while orders, payment and delivery are done through offline, directly to the advertiser. Then the advertisers pay some amount of money as transaction fee to the classified ads management. Kaskus, tokobagus, berniaga.com, OLX.com are example of classified ads.

2. Daily Deals

Daily deals are activities to give place of business in the form of daily deals sites as means for daily deals merchant to sell goods or services to buyers using vouchers as means of payment. Number of sellers are lots with incidental promotional activities in sales. Offers and orders are through online while payment and delivery are through online or offline. The payment can be done directly or through website. The goods can be directly picked up or through delivery. Example of daily deals are groupon disdus, traveloka, tiket.com, pegipegi. 


\section{Online Retail}

Online retail are activities to sell goods or services to buyers directly from online retail management in online retail sites. Number of seller is only one and permanent who owned the online retail. Offers are through online while orders, payments and delivery are through online or offline. The payment can be done directly or through website. The goods can be directly picked up or through delivery. Example of online retail are blibli.com, bhinneka.com, lazada.com.

\subsection{Tax on e-commerce transactions}

Tax on e-commerce transactions is actually almost the same with other type of business taxation. The most common taxation that must be paid by taxpayers in e-commerce industry is income tax and value added tax. Income tax is based on Income Tax Law No 36 of 2008. Most e-commerce taxpayers have to pay for final income tax as long as sales amount is below 4.8 billion per year. Tax rate for the final income tax as referenced in Government regulation No 23 Year 2018 is 0,5\%. Final tax income cannot be used as credit tax for tax payable at the end of tax year. If sales is more than 4.8 billion per year then general tax rate of $25 \%$ will be applied.

Another tax that must be concerned of e-commerce tax payers is Value Added Tax on Goods and Services and Sales Tax on Luxury Goods Law No 42 of 2009. General tax rate for value added tax is $10 \%$. There is obligation for VAT taxable enterprise either e-commerce personal or corporate taxpayers once sales is more than 4.8 billion per year. Other tax is sales tax on luxury goods. Tax rate in range between $10 \%$ until $200 \%$ must be paid for goods categorized as luxury goods.

A new rule of VAT, Minister of Finance Regulation No 48/PMK.03/2020 about procedures of collection, payment and reporting of Value Added Tax for intangible goods and or services from abroad, which are used in Indonesia through electronic system trade was just released on 5 May 2020 and will be enforced starting on 1 July 2020. VAT will be charged to e-commerce tax payers with certain criteria. Two criteria including amount of transactions in twelve months that more than specific amount and amount of traffics in specific website or online platform in twelve months that more than specific amount.

For e-commerce corporate tax payers, book keeping obligation has to be fulfilled at any amount of sales, starting at the company is founded. Meanwhile no bookkeeping obligation for ecommerce personal taxpayers with sales amount of below 4.8 billion per year, but e-commerce personal taxpayers still have to record sales with supporting documents needed to calculate income tax. For e-commerce personal taxpayers with sales amount of more than 4.8 billion per year, there is obligation of book keeping. Tax rate will be applied based on profit as taxable income. For foreign ecommerce tax payers, they will be a subject of additional on income tax Art 26 of 20\%, if they have office and or representatives (Permanent Establishment) in Indonesia.

If they do not have Permanent Establishment in Indonesia, government cannot charge corporate income tax to them, even though these foreign e-commerce tax payers have already high amount of sales (market) in Indonesia. This condition makes the competition unfair between foreign e-commerce tax payers and local e-commerce tax payers. Unfairness also happened when government did not enforce tax rules to e-commerce tax payers, while brick and mortar tax payers have to pay taxes. Those conditions which some taxpayers pay taxes, while some others don't, will lead directly to unfairness.

According to Smith (1976:36), taxation should be imposed according to the famous canons of equality, certainty, convenience, and economy and insisted that they should not be levied in ways which infringed the liberty of the subject. Equality means that tax will be charged to personal tax payers or corporate tax payers in fair and equal to tax payers ability to pay and benefit received. According to Musgrave (Waluyo, 2017:14), there is two kinds of fairness principles in taxation:

1. Benefit principle. Every tax payers must pay taxes equal to benefit that received from government. This approach called as revenue and expenditure approach

2. Ability principle. This approach advised that tax should be charged to tax payers from ability to pay point perpectives. 
According to Mansury (Waluyo, 2017:15), fairness in taxation can be divided into two types, horizontal fairness and vertical fairness. Horizontal fairness happens if tax burden is the same for all tax payers, which have the same income with the same expenditure, without make any differences to type or source of income. In horizontal fairness, equal treatment for the equals applied, means that all incomes are charged with the same tax rate without any differentiation in type or source of income. Vertical fairness happens when tax payers with the same economic conditions will have the same tax burden, vice versa. Unequal treatment for the unequals applied in vertical fairness, means that tax rates are differentiated through income received.

It is a big challenge for government to implement tax on e-commerce transactions in term of fairness. Regulation based on physical presence should be changed to significant economic presence as new nexus inline with substance over form principle and Unified Approach (Pillar One) of OECD to gain tax revenue for government and make the business competition is fair.

\section{Research methodology}

This research used qualitative research. According to Creswell (2018:297), qualitative research is an inquiry process of understanding based on distinct methodological traditions of inquiry that explore a social or human problem. It builds a complex, holistic picture, analizes word, report detailed views of information, and conducts the study in a natural setting. This research used descriptive method. Interview, observation and documentation are used to collect data. Semistructured interview was used to get comprehensive information about implementation of taxation in e-commerce industry.

Information gathered from tax officer of Directorate General of Taxation, Jl Gatot Subroto Kav No 40-42, Jakarta, Income Tax division and Value Added Tax Division II (Mr. Linggo Saputro, S.ST), 5 taxpayers of e-commerce industry and 5 taxpayers of non e-commerce industry. Source of data for this research is from primary data directly from interviewees as research object. Documentation method is a method to collect data in the form of documents, notes and others about implementation of e-commerce taxation. Collected information will give description about current implementation of e-commerce taxation with further exploration of factors that supporting and factor that will be constraints for e-commerce taxation implementation. Interview questions list for fiscus and e-commerce taxpayers are available in index of this research.

\section{Results and discussions}

The rise of e-commerce growth in Indonesia is very fast. According Statista's Indonesian Digital Market Outlook Report (Statista, 2019), revenue in the e-commerce market is projected to reach US $\$ 28,597 \mathrm{M}$ by the end of 2020 , while annual growth rate for revenue is expected to show Compound Annual Growth Rate (CAGR) 2020-2024 of 15.4\%, resulting in a projected market volume of US $\$ 50,662 \mathrm{M}$ by 2024. Market's largest segment is fashion with a projected market volume US\$ 8,521 M in 2020. User penetration will be 50.5\% in 2020 and expected to hit $73.3 \%$ by 2024. Average Revenue Per User (ARPU) is amount to US\$207.09. This amount will be adjusted higher due to expected impact of Covid 19 in 2020.

This condition is good news to government (Directorate General of Taxation) as higher revenue will be reserved. But the implementation of e-commerce taxation brings its own challenges and constraints. According to Directorate General of Taxation Circular No 62 Year 2013 about taxation of e-commerce transactions, there are four types of e-commerce transactions including online marketplace, classified ads, daily deals, and online retail. Tax obligations are including Income Tax and Value Added Tax. Income tax for e-commerce tax payers with sales below 4.8 billion is final income tax $0.5 \%$. Obligation of value added taxable enterprises will arise if sales is more than 4.8 billion. For value added tax, the tax rate is $10 \%$. Lots of e-commerce taxpayers do not pay taxes as some of them do not know about taxation and some do it as tax evasion. 


\section{Constraints to implement e-commerce taxation}

Some constraints in implementation of e-commerce taxation:

1. E-commerce transactions are quite difficult to detect.

E-commerce business uses internet as backbone for its business, so the process of transactions can be progress really quick and efficient. These characteristics are differentiation than other conventional business (brick and mortar stores), but at the same time, these characteristics are also brings difficulties to government (Directorate General of Taxation) to detect and establish clear and fair tax regulations for e-commerce industry

According to Resmi (2019:12), there are two types of taxes. First, direct taxes are taxes that are paid by tax payers directly to government. Examples: Income tax, land and building tax, etc. Second, indirect taxes are taxes that are subject to taxpayers, but it will be burdened for other person or entities. Example of indirect tax is value added tax. According to Mr. Linggo Saputro, tax officer of Directorate General of Taxation, for income tax which are direct tax, there are two constraints in e-commerce taxation due to the characteristics of e-commerce business:

a.. Uncertainty place of business.

In conventional stores (brick and mortar stores), Directorate General of Taxation will charge for all of the business activities. When the business wants to expand by opening new stores, new tax identification number will be needed to progress as branch of the headquarter tax identification number and all rights and obligations of the new stores. The place and form of business are easily identified by physical presence of the store and its activities. But in online stores, there is no need to open branches anymore because in ecommerce the business process is more free to sell products to any countries with around the world market coverage. This makes uncertainty place and form of business in comparison with conventional business.

b. Difficulties in tracing personal or corporate identity

The place and form of business are easily identified by physical presence of the store and its activities. In e-commerce it is really difficult to trace personal or corporate identity without using high technology. It makes Directorate General of Taxation has difficulties in implementing e-commerce taxation.

For indirect tax, there are two constraints also in e-commerce taxation due to the characteristics of e-commerce business:

a. Arising of New digital products

Development in digital information in recent years has been very fast changing.

New kind of digital products has been released like digital book, software, songs, video, movies, etc can be sold through online. Physical appearance of those digital products can not be seen. Directorate General of Taxation is really difficult to identifiy and chase taxpayers for this type of digital products.

b. Difficulties in tracing digital products in cross border e-commerce transactions

The online transactions for digital products often is cross border transactions like Netflix. It makes those digital products will be free of value added tax charge. For example, a person in Indonesia buys a digital book from online store in United States of America. When digital book arrives in computer of buyer in Indonesia, that transaction will not be charged of value added tax or import tax. This will be totally different situation with non digital book. When this non digital book arrived in Indonesia, it will be charged according to tax regulation in Indonesia. Potential tax revenue either on sellers or buyers countries may diminish and not be detected by tax authorities of both countries. This challenges happened and it is the hot constraints in Indonesia and around the world for taxation of ecommerce transactions.

2. Low understanding of taxation of e-commerce transactions

Most taxpayers including e-commerce taxpayers still have low understanding of tax regulations. At the same time, tax system in Indonesia is using self-assessment. Taxpayers have full 
responsibilities to calculate, pay and reporting of their own taxation to tax office. Low understanding of tax regulations made taxation of e-commerce transactions can not be realized in a good manner. According to some taxpayers that interviewed, they still do not understand about e-commerce taxation. A taxpayer who has new start up business did not know that taxpayer should calculate, pay and reporting to tax office, but he understood that he has to get tax identification number. But most taxpayers still do not know tax regulation for e-commerce transactions.

3. No comprehensive socialization for taxation of e-commerce transactions

Low Understanding of taxpayers for e-commerce taxation is in line with low socialization from Directorate General of Taxation. According to Mr. Linggo Saputro, socializations has ever been done at the beginning of Circular No 62 Year 2013 about taxation of e-commerce transactions released but high growth of taxpayers in e-commerce industry needs another socializations. Most taxpayers who are interviewed stated that have never got any socializations about taxation of ecommerce transactions and they are really want to have it because not all formal education of taxpayers are in economics. In general all taxpayers said that they are ready to help Directorate General of Taxation implementing e-commerce tax regulations if they have further education about e-commerce taxation.

4. Supervisory activities from Directorate General of Taxation are not in optimum stage. Mr. Linggo Saputro said that till recently Extensification Division of Directorate General of Taxation only socializes rules. For current tax payers that has been already in Directorate General of Taxation system, they will be in supervisory and consultation division monitoring, but for new taxpayers or e-commerce businesses which do not have tax identification number will be in extensification monitoring. Directorate General of Taxation still tries to think how to tax ecommerce taxation in efficient way with less efforts, so Directorate General of Taxation does not have to find one by one taxpayers either personal or corporate taxpayers.

There are four concerns of Directorate General of Taxation, as mentioned by Mr. Linggo Saputro, for implementing taxation of e-commerce transactions:

1. Difficulties in the detection of e-commerce transactions brought its own problems, this was the biggest challenge in e-commerce transactions. It will lead to the difficulty for the government to establish a clear and fair e-commerce tax rules

2. Market place platform provider should have obligation to prepare tax payment system or virtual tax identification number to e-commerce taxation

3. E-commerce taxpayers also want to have fairness, so tax will also implement to social media, advertisers in newspapers, etc.

4. Socialization is needed, so e-commerce taxpayers really understand that they have the same tax obligation as brick and mortar store taxpayers. Directorate General of Taxation can also socialize tax payment obligation through social media and or e-commerce platform, so ecommerce taxpayers and their buyers will understand about e-commerce taxation that must be fulfilled.

Directorate General of Taxation really understand that there are also weaknesses in regulation for ecommerce taxation implementation. Lots of loopholes can be used by taxpayers to avoid e-commerce taxation. One of Directorate General of Taxation efforts by releasing some new regulations to cover loopholes. Directorate General of Taxation released Minister of Finance Regulation No 210/PMK.010/2018, released on 31 December 2018 about Taxation of E-Commerce Transactions. Some important points of this regulations are:

1. For merchants, they have to:

a. Informed tax identification number to online marketplace management

b. If merchants do not have tax identification number, they can propose tax identification number to tax office or inform ID number to online marketplace management

c. Fulfill income tax as mentioned in tax regulation like final income tax $0,5 \%$ from sales when sales is not more than 4.8 billion in a year. 
d. Registered as VAT taxable enterprises if sales is more than 4.8 billion in a year and do all obligation as VAT taxable enterprises.

2. For online marketplace management, they have to:

a. Have tax identification number and registered as VAT taxable enterprises.

b. Levy, pay and report income tax and value added tax of platform services to merchants.

c. Levy, pay and report income tax and value added tax for sales of online marketplace.

d. Report recapitulation of merchants transactions.

3. For e-commerce taxpayers, outside online marketplace, either through online retail, classified ads, daily deals and social media have to obey all tax regulations including income tax, value added tax and sales tax on luxury goods

Even though this Minister of Finance Regulation No 210/PMK.010/2018 about Taxation of ECommerce Transactions was released on 31 December 2018, but it will take in effect as of 1 April 2019, but unfortunately before this rule takes in effect, it was cancelled on 29 March 2019. The reason for this cancellation that government thought that there should be comprehensive coordination and synchronization between government institution before the rule takes in effect. Some e-commerce taxpayers who interviewed thought that this cancellation made e-commerce taxation is still not clear yet, while for non e-commerce taxpayers this cancellation was a sign of no fairness for taxation between online stores and offline stores and they started asking for government firmness.

Recent regulation of e-commerce was released on 25 November 2019, Government Regulation No 80 Year 2019 about trading through electronic system, but this regulation is not as clear and detail as Minister of Finance Regulation No 210/PMK.010/2018 about Taxation of E-Commerce Transactions which were released on 31 December 2018. In this regulation, Directorate General of Taxation wanted to give guidance for e-commerce companies or businessmen from abroad and accommodate economic substance from Public Consultation of Unified Approach of OECD which was released on October 2019. Even though, Unified Approach of OECD has not been settled yet, but concept of new nexus has been adopted by some countries in the world. New nexus on economic substance, not physical presence, depends on the market which consumers are domiciled, the country of consumers will have the right to tax for the e-commerce transactions, even though sellers are in abroad, not in the same country with the buyers.

This economic substance can be seen in Article 7 (1) of Government Regulation No 80 Year 2019 about trading through electronic system, E-Commerce companies or businessmen from abroad who actively doing offer to consumers in Indonesian law juris diction with certain criteria will be assumed fulfilling physical presence in Indonesia \& have Permanent Establishment (PE). In Article 7 (2), criteria will be detailed in further regulations but it will be based on amount of transaction, value of transaction, amount of delivery, amount of traffic or accessers. Additional requirement from Directorate General of Taxation stated in Art 7 (3) E-Commerce companies or businessmen must appoint representative that based in Indonesia and this representative will be on behalf of the eCommerce companies or businessmen. Explanation of Article 11 which stated that all of e-commerce companies or businessmen must fulfill license and other requirements for doing business including taxpayer identification number, this article gives affirmation about the importance of taxpayer identification number.

According to taxpayers interviewed, this regulation is good progress, but it does not give any guidance for domestic e-commerce taxpayers, rather it is a step ahead to close loopholes for tax avoidance by foreign e-commerce taxpayers who have market or consumers in Indonesia. Latest update of e-commerce taxation, according to Suwiknyo (2019), digital or e-commerce taxation will be included in Omnibus Law. Omnibus Law is comprehensive of several laws including taxation at the same time that will be released next year. Currently this Omnibus Law draft is still on the hand of Indonesian house of representative for review. Some important points of e-commerce transactions in Omnibus Law are: 
1. Income tax and value added tax mechanism. Omnibus Law will emphasize payment obligation of Income tax and value added tax from e-commerce transaction income of domestic taxpayers.

2. Value added tax mechanism for intangible taxable goods and services from foreign taxpayers. Directorate General of Taxation will appoint foreign marketplace platform to levy and pay value added tax.

3. Foreign e-commerce tax mechanism for goods and services either through direct or foreign marketplace platform.

\section{Conclusion}

E-commerce business in Indonesia is in high growth stage. High growth of e-commerce activities makes government realize that e-commerce industry really needs urgent trade and tax regulations. Current tax regulations are including Income Tax and Value Added Tax. Income tax for e-commerce tax payers with sales below 4.8 billion is final income tax $0.5 \%$. Obligation to become value added taxable enterprises will arise if sales is more than 4.8 billion. For value added tax, the tax rate is $10 \%$. Lots of e-commerce taxpayers do not pay taxes as some of them do not know about taxation and some do it as tax evasion. Some challenges in implementation of e-commerce taxation are e-commerce transactions are quite difficult to detect, low understanding of taxation of ecommerce transactions, no comprehensive socialization for taxation of e-commerce transactions and supervisory activities from Directorate General of Taxation are not in optimum stage.

Some taxpayers interviewed mentioning e-commerce taxation is not clear yet, but they felt there is unfairness in practices between e-commerce (online) stores and conventional brick and mortar (offline) stores. Based on analysis above about e-commerce transaction, we can conclude that socialization of e-commerce taxation and monitoring to e-commerce taxpayers are important. Directorate General of Taxation must coordinate with other institutions like e-commerce businesses association, Ministry of Communication and Information Technology, Directorate General of Customs and Excise, banks, delivery companies, etc. Directorate General of Taxation must develop regulations to close loopholes for tax avoidance and tax evasion in e-commerce industry. Regulation based on significant economic presence should be made as new nexus inline with substance over form principle and Unified Approach (Pillar One) of OECD to gain revenue for government. Clear and fair tax regulations are needed to keep fairness between conventional businesses and e-commerce businesses.

\section{Limitation and Study Forward}

This research has limitation in amount of interviewees due to time limitation. In future research, amount of interviewees can be added and split into four types of e-commerce transactions according to Directorate General of Taxation Circular No 62 Year 2013 to get more in-depth analysis and conclusion for each type of e-commerce transactions.

\section{Acknowledgement}

I would like to acknowledge and thank for all supports in this research especially to Directorate General of Taxation (Mr. Linggo Saputro) and all the interviewees. Thanks also to Prof William Byrnes from Texas A\&M University who always gives motivation and supports to write journal in taxation area.

\section{References}

Aprilia, A., Astuti, E. S., \& Nuzula, N. F. (2013). Penanganan dan pengawasan perpajakan dalam rangka intensifikasi di bidang e-commerce. Journal of Chemical Information and Modeling, 53(9), 1689-1699. https://doi.org/10.1017/CBO9781107415324.004

Cambridge University Press. (2019). Cambridge dictionary.

Directorate General of Taxation. (2007). General tax provisions \& procedures law No 28 of 2007. Jakarta: Finance Ministry.

Creswell, J. W \& Creswell, J.D. (2018). Research design: Qualitative, quantitative and mixed method approaches. United States of America: Sage Publications, Inc. 
Directorate General of Taxation. (2008). Income Tax Law No 36 of 2008. Jakarta: Finance Ministry.

Directorate General of Taxation. (2009). Value added tax on goods and services and sales tax on luxury goods law No 42 of 2009. Jakarta: Finance Ministry.

Directorate General of Taxation. (2013). Circular No 62 Year 2013 about taxation of e-commerce transactions. Jakarta: Finance Ministry.

Finance Minister. (2018). Minister of Finance Regulation No 210/PMK.010/2018 about taxation of ecommerce transactions. Jakarta: Finance Ministry.

Finance Minister. (2020). Minister of Finance Regulation No 48/PMK.03/2020 about procedures of collection, payment and reporting of Value Added Tax for intangible goods and or services from abroad which are used in Indonesia through electronic system trade. Jakarta: Finance Ministry.

Indonesian Central Bureau of Statistics. (2019). Statistik e-commerce 2019, Accessed from https://www.bps.go.id/publication/2019/12/18/fd1e96b05342e479a83917c6/statistik-ecommerce-2019 on 20 December 2019

Irmawati, D. (2011). Pemanfaatan e-commerce dalam dunia bisnis. Orasi Bisnis.

Machine, M. (2019). Saturated sectors: Finding gaps in the ecommerce market in 2019. Accessed from https://merchantmachine.co.uk/saturated-sectors/ on 15 December 2019

Makalalag, L. (2016). Pengenaan pajak penghasilan terhadap pengusaha dalam transaksi perdagangan online (e-commerce). Jurnal Ilmu Hukum Legal Opinion. https://doi.org/10.1360/zd-2013-436-1064

President of Indonesian Republic. (2019), Government Regulation No 80 Year 2019 about trading through electronic system. Jakarta: Law and Human Rights Ministry.

Resmi, S. (2019). Perpajakan: Teori dan kasus. Buku 1. Edisi 11. Jakarta, Indonesia: Salemba Empat

Rivera, A. (2018). What is B2B, B2C, C2B, C2C ? Accessed from https://www.businessnewsdaily.com/5084-what-is-c2c.html on 17 December 2019.

Satista. (2019). Indonesian Digital Market Outlook Report. Accessed from https://www.statista.com/outlook/243/120/ecommerce/indonesia on 31 December 2019.

Smith, A, (1976). An inquiry into the nature and causes of the wealth of the nations. Oxford University Press.

Suwiknyo, E. (2019). Omnibus Law Perpajakan Atur Pemajakan Transaksi Digital. Accessed from https://ekonomi.bisnis.com/read/20191217/259/1182104/omnibus-law-perpajakan-aturpemajakan-transaksi-digital on 17 December 2019.

Waluyo. (2017). Perpajakan Indonesia. Edisi 12. Buku 2. Jakarta, Indonesia: Salemba Empat

\section{$\underline{\text { Appendices }}$}

\section{Interview Questions List for Fiscus}

1. Definition of e-commerce

a. What type of online sales that will be subject to tax?

b. How many e-commerce businesses that have already registered as taxpayers in Indonesia?

c. What if the product is digital like online game, digital book? Is it in the definition of ecommerce?

2. Taxation of e-commerce

a. Are there any taxation of e-commerce transactions in Indonesia? If yes, since when? If no, is there any plan to implement it?

b. Are there any differences of taxation between e-commerce transactions and conventional transactions (brick and mortar stores)?

c. What next steps will Directorate General of Taxation take in the future?

3. E-commerce taxation mechanism

How is e-commerce taxation mechanism? 
4. Collecting mechanism of e-commerce transactions

a. How is calculating and collecting mechanism of e-commerce transactions?

b. What kind of taxes are charged to e-commerce transactions?

5. Monitoring system of e-commerce taxation

How to monitor implementation of e-commerce taxation?

6. Supporting factors in the implementation of e-commerce taxation

What are supporting factors in government decisions in the implementation of e-commerce taxation?

7. Constraints in the implementation of e-commerce taxation

Are there any constraints in taxation of e-commerce transactions in Indonesia?

8. Any advises for Indonesian taxation especially for e-commerce industry?

\section{Interview Questions List for Taxpayers}

1. Understandings of e-commerce taxation

a. What do you know about taxation?

b. What do you know about taxation of e-commerce transactions?

c. Will you pay taxes of e-commerce transactions? Why?

2. Taxpayers' opinion for taxation of e-commerce transactions

a. What do you think about implementation of e-commerce taxation ?

b. Any advises for Indonesian taxation especially for e-commerce industry? 